\title{
Protection Of Indonesian Cultural Heritage Through Sui Generis Law
}

\author{
Diah Imaningrum Susanti \\ Lecturer, Faculty of Law, Widya Karya Catholic University \\ Malang, East Java, Indonesia
}

Rini Susrijani

Lecturer, Faculty of Economics, Widya Karya Catholic University

Malang, East Java, Indonesia

\begin{abstract}
Indonesia's copyright law is inadequate to protect Traditional Cultural Expression (TCE) because moral rights and economic rights in copyright law cannot be applied to TCE. The State/Government as copyright holder of TCE is also a false concept as it is a political entity that has no right to hold the moral and economic rights. Regulating TCE in different laws raises "overlapping" legal consequences. A sui generis law might be more appropriate for cultural heritage protection as it specifies the policy objectives, subject matter, criteria, the owner of the rights, the kind of and the way the rights are administered and enforced, as well as when the rights are lost and expire.
\end{abstract}

Keywords: Copyright, Cultural Heritage, Indonesia, Sui Generis, Traditional Cultural Expression

\section{INTRODUCTION}

"Cultural heritage" includes both tangible and intangible heritage, known as Traditional Cultural Expression (TCE). Through these tangible and intangible forms, traditional knowledge and cultures are expressed, communicated, or manifested ${ }^{1}$. Indonesia is the world's latest archipelago and home to a multitude of diverse ethnic cultures, customs, value systems and ancestral heritages. As in many other Asian countries, Indonesia's cultural life has witnessed attempts by various commercial interests to exploit it. The age-old cultural practices and expressions of art, craft and music were exploited by enterprising businessmen to further their own economic gains. The impact of this process has gradually affected the mindset of the indigenous people. Many Indonesians have begun to consider legal protection for the rights of their intellectual creations ${ }^{2}$.

Indonesia has ratified the Convention for the Safeguarding of the Intangible Cultural Heritage, put in force by the Presidential Decree No. 78/2007. Nevertheless, the protection of these expressions is provided by Copyright Law, in which the holder of the copyright is the State ${ }^{3}$.

\footnotetext{
${ }^{1}$ World Intellectual Property Organization (WIPO), Glossary of Key Terms Related to Intellectual Property and Traditional Knowledge (WIPO), 2012, http://www.wipo.int/meetings/en/doc_details.jsp?doc_id=167787 (accessed 7 May 2017), p. 26.

2 Valsala Kutty, National Experiences with the Protection of Expressions of Folklore/Traditional Cultural Expressions (Geneva: WIPO Publications, 2002), http://www.wipo.int/edocs/pubdocs/en/tk912/wipo_pub_912.pdf (accessed 7 May 2017), pp. 33-34.

3 Indonesia's Law No. 6/1982, Law No. 7/1987, Law No. 19/2002, and Law No. 28/2014 on Copyright.
} 
Legal protection in TCE context means that there are (1) rules encouraging and supporting the exchange of the holders' knowledge, innovations, and traditional practices between themselves; (2) the right to oppose any research disregarding the respect for and recognition of indigenous rights; (3) assurances that any transaction aiming at destroying or discrediting the integrity of the indigenous knowledge, innovations, and practices is void; (4) elaboration and legal implementations of strategies to "thwart plans" which "adversely affect" indigenous knowledge, innovations, and practical traditions, especially third-party mega-projects in indigenous territories; (5) assurances that the common use of biological and other resources relating to traditional knowledge remains free, especially within a system for the protection of collective property rights 4 .

The protection of TCE in Indonesia has become problematic since Indonesian Government issued the Law on Copyright in 1982, as there are no implementation rules and there is no institution representing the State in the protection of TCE ${ }^{5}$. The role of Indonesian government as copyright holder has been critiqued, as in Aragon's research ${ }^{6}$ on intangible property nationalism. Furthermore, three Indonesian Copyright Laws have been passed without academic texts and so it is difficult to find out the legislators' intention in including TCE in this copyright regime ${ }^{7}$.

In fact, TCE in Indonesia does not enjoy proper protection: a wayang (shadow puppet) show was forcefully shut down by a radical group in Solo City, being accused of contradicting Islam ${ }^{8}$. A statue of Arjuna in Purwakarta City had been destroyed by another radical Islamist group ${ }^{9}$. In the case of intangible property, the findings of Nahor ${ }^{10}$, Kusumadara ${ }^{11}$, and Mahadewi ${ }^{12}$ confirm that many music, dances, and Balinese traditional silver craft had been appropriated and copyrighted by foreign companies. A study by Sinaga ${ }^{13}$ showed that some community members (e.g. small and medium batik enterprises) cared little for TCE in the copyright model,

\footnotetext{
${ }^{4}$ Anna Friederike Busch, Protection of Traditional Cultural Expressions in Latin America (Berlin: Springer, 2015).

${ }^{5}$ Rafles Junarto Nahor, Perlindungan Hukum Hak Cipta Folklor Atas Tari-Tarian Rakyat Indonesia [Copyright Law Protection of Indonesian Folklore Dances] (Yogyakarta: Atma Jaya University, 2013), available from http://ejournal.uajy.ac.id/315/1/0MIH01582.pdf (accessed 19 June 2017)

${ }^{6}$ Lorraine Aragon, "Copyrighting Culture for the Nation? Intangible Property Nationalism and the Regional Arts of Indonesia”, (2012), 19(3), International Journal of Cultural Property 269-312, p. 269.

7 Diah Imaningrum Susanti, 'Ekspresi Budaya Tradisional dalam Undang-Undang Hak Cipta Indonesia: Kajian Maksud Pembuat Undang-Undang dan Kajian Perbandingan Hukum [Traditional Cultural Expressions in Indonesian Copyright Law: Study on the Intent of Lawmakers and Law Comparison]', Internal research paper, Widya Karya Catholic University, 2016.

${ }^{8}$ No name, 'Menembus Brunei, Gamang di Negeri Sendiri [Breakthrough in Brunei, uneasiness in home country]', Kompas, 2010

${ }^{9}$ Mike Reyssent, 'Patung Arjuna dihancurkan mengapa patung polisi dibiarkan [Why the Statue of Arjuna is Destroyed but Police Statues are Allowed]', Kompasiana, 16 February 2016, available from https://www.kompasiana.com/mikereys/patung-arjunadibiarkan_56bfd884ad7e61fa0f44608b (accessed 10 May 2017)

10 Nahor.

11 Afifah Kusumadara, "Pemeliharaan dan Pelestarian Pengetahuan Tradisional dan Ekspresi Budaya Tradisional Indonesia: Perlindungan Hak Kekayaan Intelektual dan Non-Hak Kekayaan Intelektual [Protection and Preservation of Indonesian Traditional Knowledge and Cultural Expressions: Protection of Intellectual Property Rights and Non-Rights]" (2011) 18(1) Ius Quia Iustum 20-41.

12 Kadek Julia Mahadewi,'”Budaya Hukum Dalam Keberlakuan Undang-Undang Nomor 28 Tahun 2014 Tentang Hak Cipta Pada Pengrajin Perak Di Bali [Legal Culture in the Application of Indonesian Copyright Law No. 28 of 2014 to Balinese Silversmiths]" (2015) 4 (2) Udayana Master Law Journal 205-218.

13 V Selvie Sinaga, "Faktor-Faktor Penyebab Rendahnya Penggunaan Hak Kekayaan Intelektual di Kalangan Usaha Kecil Menengah Batik [Factors behind the Low Use of Intellectual Property Rights among Small and Medium Batik Enterprises]" (2014) 21(1) Ius Quia Iustum 61-80.
} 
because the model cannot accommodate the special circumstances of Indonesian batik, while the administration system of the intellectual property right is unaccommodating and its enforcement is weak. So far documentations of TCE conducted by the government are limited to those that have already been globalized, such as shadow puppet, kris, and batik ${ }^{14}$.

Among Asian countries, Indonesia is very late in giving proper attention to the protection of its traditional knowledge and folklore. Indonesia's attention toward this issue has only been awaken in the past three years, following disputes with neighbor Malaysia over some Indonesian traditional knowledge and folklore. For instance, Malaysia claimed Indonesian art such as Pendet dance from Bali, Reog dance from Ponorogo (East Java), Rasa Sayange song from Ambon, and Indonesian batik, to promote its own tourism. There were also some disputes over Japanese patents on Indonesian traditional knowledge. For example, Shiseido, a Japanese cosmetic company, had patented Indonesian traditional knowledge and 11 different compounds of Indonesian traditional medications (jamu), although in 2002 they withdrew those patents from the European Patent Office amidst strong protests by some Indonesian NGOs, such as BioTani PAN Indonesia ${ }^{15}$. Most Indonesian see the misuse and misappropriation of Indonesian traditional knowledge and folklore as a very sensitive issue that insults the identity and pride of Indonesians. Therefore, the Indonesian government is forced to start considering protecting Indonesian traditional knowledge through an appropriate legal protection model.

The legal and sociological problems are exacerbated by globalization which increases intercultural frictions that may create social tensions among communities and identity claims ${ }^{16,17,18}$. TCE consequently became the subject of predatory acquisition by trans-national entrepreneurs ${ }^{19}$. Technologies have often been seen as imperiling TCE and inhibiting their protection. The first reason for this concern is that new technologies are viewed as the very epitome of globalization forces - both as driving and deepening the globalization process itself and as a means of spreading its effects ${ }^{20,21}$.

This needs a critical understanding of the meaning of "the State as copyright holder in TCE" as in Indonesian copyright law and its juridical consequences.

Some legal problems explored here: 1) Why Indonesian copyright law is inadequate to protect TCE?; 2) What is the interrelation between Indonesian copyright law and culture-related regulations in the context of cultural heritage?; 3) How can a sui generis law be appropriate for cultural heritage protection?

\footnotetext{
14 Kusumadara.

15 Kusumadara.

16 UNESCO, Berinvestasi dalam Keanekaragaman Budaya dan Dialog Antarbudaya [Investing in Cultural Diversity and Intercultural Dialogues] trans. Dwi Indrasari (Paris: UNESCO, 2011), p.11.

17 Christoph Antons, "Asian Borderlands and the Legal Protection of Traditional Knowledge and Traditional Cultural Expressions" (2013) 47(4), Modern Asian Studies 1403-1433, p. 1403.

18 Mira Burri, "Digital Technologies and Traditional Cultural Expressions: A Positive Look at a Difficult Relationship" (2010) 17(1) International Journal of Cultural Property 33-63, p. 3.

${ }^{19}$ Adebambo Anthony Adewopo, "Protection of and Administration of Folklore in Nigeria" (2006) 3(1) SCRIPTed 1-10, p. 10.

${ }^{20}$ Christoph Beat Graber and Mira Burri, Intellectual Property and Traditional Cultural Expressions in a Digital Environment (Cheltenham: Edward Elgar, 2008).

21 Paul Kuruk, "African Customary Law and the Protection of Folklore" (2002) 26(2) Copyright Bulletin 4-32.
} 


\section{METHODS}

The material objects of this study are Indonesian regulations on Traditional Cultural Expression, in the form of Copyright Law, the Bill of Government Regulation on Copyright of Traditional Cultural Expressions held by the State, and International Conventions dealing with Traditional Cultural Expressions and cultural heritage. The formal object or perspective and approach used in understanding those texts is Hans-Georg Gadamer's legal hermeneutics. This perspective is characterized by "dialogues" and comprehensive analysis of a text in a circle in which the parts cannot be separated from the whole and the whole cannot be separated from the parts, in order to get a comprehensive understanding, conducted through linguistic and phenomenological analysis ${ }^{22}$.

One key aspect of the legal dimension of this topic is prejudice or preconception, in Gadamer's term - Vorverständnis - we all bring our prejudices to any topic we attempt to comprehend. In general, this preconception is essential for and relates to the whole "issue of law"23. The "dialog" between the interpreter (researcher) and the text enables the text to be understood comprehensively, through linguistic and phenomenological - philosophical, historical and comparative - analysis ${ }^{24}$.

The primary sources of this research are: Indonesian Law No. 28 of 2014 on Copyright, Presidential Regulation No. 28 of 2007 on the Ratification of the Convention for the Safeguarding if Intangible Cultural Heritage, UNESCO Convention for the Safeguarding of Intangible Cultural Heritage, Convention on Biological Diversity, WIPO Model Law for Folklore Protection 1982, WIPO Draft Treaty on Protection of Folklore, WIPO Draft Treaty on Protection of Traditional Knowledge, WIPO-IGC Draft of the Protection of Traditional Cultural Expressions/Expressions of Folklore: Revised Objectives and Principles, WIPO-IGC Draft of the Protection of Traditional Knowledge: Revised Objectives and Principles. The secondary sources are dictionaries and encyclopedia, and writings in books and journals dealing with TCE.

Linguistic analysis is used to find out the meaning from linguistic perspective, as language is essentially the core of being, and the only being that can be understood is language ${ }^{25}$. Because law is wrapped in language, this perspective is relevant and important. The philosophical approach is used to find out the essence of the State as the copyright holder of TCE. Historical approach is used to trace back the legislators' considerations in formulating the regulation. Comparative approach is used to analyze cultural heritage in national and international contexts.

\section{Model of TCE Legal Protection}

\section{RESULTS AND DISCUSSION}

TCE is a tradition of a societal group that is transferred through generations and is recognized as common property ${ }^{26}$. It lies in the interface between copyright law and cultural practice. The protection of folklore through copyright obfuscates the status of folklore as a generative

\footnotetext{
22 Diah Imaningrum Susanti, Penafsiran Hukum yang Komprehensif Berdasarkan Lingkar Hermeneutika [A Comprehensive Legal Interpretation Based on Hermeneutic Circle] (Malang: Indonesian Philosophical Studies, 2015).

23 Busch.

24 Susanti, 2015.

25 Jerzy Stelmach and Bartosz Brozek, Methods of Legal Reasoning (Dordrecht: Springer Netherlands, 2006).

26 Suwardi Endraswara, Folklor Nusantara [Indonesian Folklore] (Yogyakarta: Ombak, 2013), p. 20.
} 
resource for derivative works in favor of its status as a carrier of national identity, over which the State can exercise property rights ${ }^{27}$.

There is no international mandate for the protection of TCEs, and the level of protection for indigenous and traditional works in national laws vary greatly. There is still a lack of international consensus about the type of protection that would best apply universally to traditional works. The issue has taken on new dimensions since the World Intellectual Property Organization (WIPO) established the Intergovernmental Committee on Intellectual Property and Genetic Resources, Traditional Knowledge and Folklore (IGC), that began working in 2001 for a definitive protection of $\mathrm{TCE}^{28}$. However, there are some models implemented in international level.

First, the Public Domain Model. This model treats the TCE of indigenous peoples as public domain, so anyone can make use of them, and they can continue to change and evolve. Nonindigenous people are also allowed to commercialize aspects of traditional culture, because this is believed to contribute to the transmission and dissemination of culture. The supporters of this approach believe that the adoption of this approach will help protecting the public domain without further expanding the intellectual property rights scope and it will protect the transmission of indigenous culture while giving the indigenous people opportunity to gain economic benefits from their traditional culture ${ }^{29}$. Foreign companies using traditional art designs and copyrighting them in their own countries adhere to this model.

Second, the TCE protection through intellectual property rights regime. Indonesia implements this model by including TCE in copyright law. However, Mahadewi ${ }^{30}$ shows that the copyright law model adopted in Indonesia cannot be implemented in Bali, especially concerning traditional patterns, because the Balinese see their work as part of their value system and livelihood. Likewise, Collins ${ }^{31}$ states that the protection of folklore through copyright obfuscates its status as a generative resource for derivative works in favor of its status as a carrier of national identity, over which the State can exercise property rights. It is a mistake to use copyright criteria for TCE because TCE is transmitted orally from generation to generation, and customary law contains a margin of error that makes it impossible to achieve the same level of clarity and precision frequently sought in the Western legal concept of copyright ${ }^{32,33,34}$.

Third, the sui generis model. This model will protect TCE through a specific law. WIPO model ${ }^{35}$, and Panama and Australia models are some of the examples. Australia finally included TCE in a

\footnotetext{
27 Stephen Collins, 'The Commoditisation of Culture: Folklore, Playwriting and Copyright in Ghana', PhD Thesis, University of Glasgow, 2015.

28 Janice Pilch, Traditional Cultural Expressions, Issue Brief, 2009, available from http://www.librarycopyrightalliance.org/storage/documents/issuebrieftce.pdf (accessed 7 May 2017).

${ }^{29}$ Chang Chieh Yang, "A Comparative Study of the Models Employed to Protect Indigenous Traditional Cultural Expressions" (2011) 11(2) Asian-Pacific Law \& Policy Journal 50-84, p. 84.

30 Mahadewi.

31 Collins.

32 Susanti, 2015.

33 Kuruk.

34 Manfred Hinz, "The Swakopmund Protocol on the Protection of Traditional Expressions of Folklore" (2011) 3(1) Namibia Law Journal 101-112, p. 11.

35 UNESCO and WIPO, Model Provisions for National Laws on the Protection of Expressions of Folklore against Illicit Exploitation and Other Prejudicial Actions (WIP0), 1985, available from http://www.wipo.int/wipolex/en/details.jsp?id=6714 (accessed 18 June 2017)
} 
specific law, Australian Heritage Protection Act, which is more efficient and appropriate ${ }^{36}$. Zhang ${ }^{37}$, in her research in China, proposes a legal protection by modifying the present intellectual property system (including the copyright law) and make use of every opportunity of law revision to establish a sui generis law in the regime of intellectual property for TCE protection. Malaysia also uses a sui generis model through National Heritage Act in 2005. Tunisia uses this model by combining copyright law model without terms of protection. The success of this model depends on cooperation among local communities, benefit sharing mechanism, and to what extent indigenous community's interests are effectively represented in a national law ${ }^{38}$.

Fourth, Recognition and Enforcement of the Judgments of Tribal Courts - decisions made by indigenous "courts" on TCE-related cases should be recognized and enforceable within the country as well as abroad. Recognizing and enforcing such decisions would be the most appropriate way of effectuating the traditional legal handling of TCEs, i.e. customary law, and thereby of protecting TCEs themselves ${ }^{39}$. African nations tend to emphasize the communal aspect of this model ${ }^{40}$. The protected TCE content refers only to the usual practices of that community. In Ghana, TCE is part of cultural heritage, preserved and developed by local ethnic

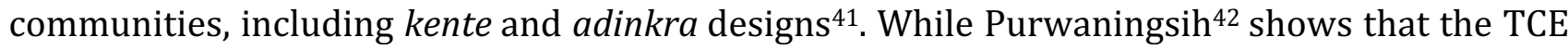
protection should be based on the needs of local community, through sustainable participation of local community.

Who protects TCE reflects two movements. First, a movement in which the meaning of a common heritage is emphasized so that it is becomes the task of international society to protect and preserve TCE ${ }^{43,44}$. Second, the meaning of a specific culture in community level, in which every culture should be appreciated, treated as important, and enforced in the ways that are equal with those recognized by the society ${ }^{45,46}$. For that reason, model business sharing is an alternative scheme from local perspective to preserve their TCE ${ }^{47}$.

The Meaning of the State as Copyright Holder of Traditional Cultural Expressions

\footnotetext{
${ }^{36}$ Jake Phillips, "Australia's Heritage Protection Act: An Alternative to Copyright in the Struggle to Protect Communal Interests in Authored Works of Folklore" (2009) 18(3) Pacific Rim Law \& Policy Journal Association 547-573.

37 Lisa Zhang, Protecting Traditional Cultural Expressions from a Copyright Perspective (IP0), 2008, available from http://www.ipo.org/wp-content/uploads/2013/03/LizaZhang.pdf (accessed 20 July 2017), p. 5

38 Antons, p. 1433.

39 Busch, p. 422.

40 Adewopo, p. 10.

41 Collins.

42 Endang Purwaningsih, "Partisipasi Masyarakat dalam Perlindungan Hukum terhadap Kekayaan Intelektual Warisan Bangsa [Public Participation in the Legal Protection of the Intellectual Property of National Heritage]" (2012) 41(1) Jurnal Masalah-Masalah Hukum FH-UNDIP 42-49.

43 UNESCO.

44 Susanti, "Penafsiran Hukum yang Komprehensif terhadap Hak Moral dan Hak Ekonomi dalam Undang-Undang Hak Cipta [A Comprehensive Legal Interpretation of Moral and Economic Rights in Copyright Law]", Seminar paper, Malang, Widya Karya Catholic University, 2014.

45 Kuruk.

${ }^{46}$ M Andhy Nurmansyah. Sony Sukmawan and Hamamah, "Strategi Pelestarian Seni Tradisi: Studi Kasus Kelompok Kesenian Tradisional Lengger di Kabupaten Jember - Laporan Hasil Penelitian Hibah Penelitian Strategis Nasional DIPA Universitas Brawijaya Tahun Anggaran 2010 [Traditional Art Preservation Strategy: Case Study of Traditional Art Community "Lengger" at Jember Residency]", Research report, Malang, Brawijaya University, 2010.

47 Krishna Ravi Srinivas, "Protecting Traditional Knowledge Holders' Interests and Preventing Misappropriation Traditional Knowledge Commons and Biocultural Protocols: Necessary but Not Sufficient?" (2012) 19(3) International Journal of Cultural Property 401-422, p. 416.
} 
The State as copyright holder of TCE supposes two propositions: 1) TCE is covered in copyright regime; 2) the State is the copyright holder of TCE.

That TCE is covered in copyright law needs to be clarified. If TCE is treated as "work" as intended in the concept of copyright law, there will be a problem on who the author and the holder of the rights are, besides the moral and economic rights as the consequences of the author's right.

The pro argument for TCE in the copyright law is that copyright law is a law that regulates science, art and literature, whereas TCE is one of the expressions of such art and literature. This argument is adhered to formally in four Indonesian Copyright Laws: Law No. 6 of 1982, Law No, 7 of 1987, Law No. 19 of 2002, and Law No. 28 of 2014, all of these are on Copyright.

The contra arguments describe theoretic-conceptual and practical difficulties in enforcing copyright law for TCE. Indonesia adheres to a civil law system in which moral right cannot be transferred, sold, or separated from economic right. The right in this context is not copyright, but author's right ${ }^{48}$.

The problem dealing with moral right in the copyright law is very unique when applied to TCE. Moral right deals with maternity right or originality which has to be the aim of author's right. The originality doctrine might be morally sound but is thorny both in its philosophy and in its practice. The most problematic dimension of the "originality" requirement in our latecapitalist economy is the intimate links between creativity and profit. Original creative works if they are profit-generating - are often caught up in elaborate industrial maneuvering and marketing packages, meaning that the efforts invested in the work comprise not only the author's labor and creativity but many other economic and aesthetic investments. While copyright, as discussed earlier, is designed to establish the legitimacy of an author, distributors create the "works made for hire" doctrine and different kinds of contractual agreements to allow an author to transfer all rights ${ }^{49}$.

The idea-expression dichotomy is the most difficult to substantiate in the area where culture meets the information sector. By closely observing the process of TCE-making, it can be concluded that such works are evolutionary, derivative, so that is difficult to prove that such works are original as aimed by copyright law. This dichotomy is related to fixation requirement that copyright comes naturally to the author when the work is created. Theoretically speaking, there is no need to obtain approval, a prior art search, or registration by any agency to qualify for copyright protection. The Berne Convention generally assumes that copyright requires no prior form of registration, and it leaves the decision about whether to require fixation to each of the member countries; neither the WIPO nor TRIPs mention fixation ${ }^{50}$. This problem would be clearly recognized as TCE tends not to be fixed in a material form.

The further difficulty is in the law enforcement of Article 44 of Law Number 28 of 2014. In that article, Indonesia's Copyright Law deems the infringement of copyright as taking the most substantial characteristic part of a work without citing the source, done not for non-

\footnotetext{
48 Paul Torremans, Intellectual Property Law (Oxford: Oxford University Press, 2006), p. 19.

${ }^{49}$ Laikwan Pang, Cultural Control and Globalization in Asia: Copyright, Piracy, and Cinema (London: Routledge, 2006), p. 27.

50 Julie Cohen et al, Copyright in a Global Information Economy, cited in Pang, Cultural Control and Globalization in Asia: Copyright, Piracy, and Cinema (London: Routledge, 2006), p. 29.
} 
commercial activities or social activities, for advocacy within or outside the court or for the sake of the blind. If TCE is covered and protected by the Copyright Law, there is a big problem on which part should be regarded as the substantial part and which part is not. TCE as cultural properties contain ethical values, social customs, beliefs or myths of which intangible heritage is the sign and expression. So it is impossible to take some parts as substantial and the rest as un- substantial and classify them as infringement. Cultural expressions are very specific and cannot be mixed with any intellectual property regimes such as copyright. The specificity of folklore is on the cultural community "owning" it, not the State. It is the cultural community that owns the folklore or generations fostered by tradition. It is not the State that has the "moral right" nor "economic right" of the folklore, as the State is not the creator, not even the right holder of the creation, because the State is a political entity, not a cultural entity 51 .

The most critical problem is the provision that the State is the holder of copyright. In Law Number 28 of 2014 on Copyright, Copyright Holder is the creator, the party receiving such rights lawfully from the Creator, or other parties who receive more rights than those who received the rights lawfully. The State as the holder has actually never received the right from the Author as required in the Article 1 (4) of the Indonesia's Copyright Law, that 'Copyright Holder shall mean the Author as the Owner of the Copyright, or any person who receives the right from the Author, or any other person who subsequently receives the right from the aforesaid person'.

The State never owns moral rights on folklore because folklore is linked with the community bearing it. As a consequence, besides the "moral right", the "economic right" is owned by the community itself. The community itself has to exploit the creation of a work to reach the largest possible market - most authors and artists have chosen to avail themselves of the possibilities created by industrialization ${ }^{52}$. The role of the State is just to protect and foster the folklore to exist and develop, as stated in the Indonesia's Constitution of 1945, including facilitating the 'economic aspect' of the folklore without holding the copyright.

It is unfortunate that Indonesia is very rich in cultural diversity and folklore but has no regulation on TCE. Nevertheless, the Indonesian Government is in the process of passing an implementation of article 44 of Copyright Law in the form of a Government Regulation. This regulation is called "Government Regulation on the Copyright hold by the State on Traditional Cultural Expression" (Hak Cipta yang Dipegang oleh Negara atas Ekspresi Budaya Tradisional). This bill defines TCE as tangible and intangible works as the object of protection, which indicate the existence of traditional culture which is held communally, passing through generations, including TCE dealing with genetic resources. This Bill has not been passed until now.

Based on the reasons stated above, it is difficult to give meaning to or understand the phrase "The State is copyright holder of TCE". This phrase has no meaning at all, as TCE is not copyright, and the State is not the copyright holder. So where TCE should be regulated or be placed? Inadequacy of Copyright Law to regulate TCE has been explained above. How about the rest?

\footnotetext{
51 Susanti, 2014.

52 Margaret Ann Wilkinson and Natasha Gerolami, "The Author as Agent of Information Policy: The Relationship between Economic and Moral Rights in Copyright” (2009) 26(2) Government Information Quarterly 321-332.
} 


\section{INTERRELATION BETWEEN COPYRIGHT LAW AND CULTURE-RELATED REGULATIONS IN THE CONTEXT OF CULTURAL HERITAGE}

Until now, Indonesia has three regulations dealing with TCE: Law Number 28 of 2014 on Copyright law (Undang-Undang Hak Cipta/UUHC), Law Number 10 of 2011 on Tangible Cultural Heritage (Undang-Undang Cagar Budaya/UUCB), and Law Number 5 of 2017 on Culture Advancement (Undang-Undang Pemajuan Kebudayaan/UUPK). The three laws deal with the products of human's mind in science, art, and literature.

UUCB protects tangible cultural heritage such as temples, monuments, landscapes, etc. This kind of properties is also regulated in UUCB on articles regulating TCE. These different regulations for one object causes overlapping in regulation, which in turn causes a legal indeterminacy: which law covers tangible traditional cultural expression? Indonesia's UUHC protects TCE (article 38) whose copyright is held by the State. The same object - TCE - is also regulated in UUCB. Article I of the UUCB defines a cultural property as of "important value for history, science, and culture", being either a man-made object or group of objects, movable (bergerak) or immovable (tidak bergerak), aged at least fifty years which has or have high historical value, or natural objects with high historical value. Said objects, under Articles IV and $\mathrm{V}$, generally belong to and are under the domain of the national government. However, Article VI allows private ownership under certain conditions. The act then goes on to regulate the search for and finding of historical objects, as well as their keeping and maintenance.

It can be seen that there is an "overlapping" between the copyright law and cultural property law in Indonesia. This overlapping is complicated by the presence of UUPK in 2017, whose objects are the object of copyright protection in TCE, i.e. oral tradition, manuscript, mores, rites, traditional knowledge, traditional technology, art, language, traditional folk game, and traditional sport. However, both TCE and Tangible Cultural Properties are objects of culture advancement. Especially, there are properties which become the cultural object covered in the three laws, e.g. traditional craft. Traditional craft could be included in TCE (and the legal consequence is that it is covered in UUHC), or in Tangible Cultural Property (and the legal consequence is that it is covered in UUCB), or in UUPK, since traditional craft belongs to traditional knowledge and art.

The interrelationship of the three Laws is illustrated in the Venn diagram below:

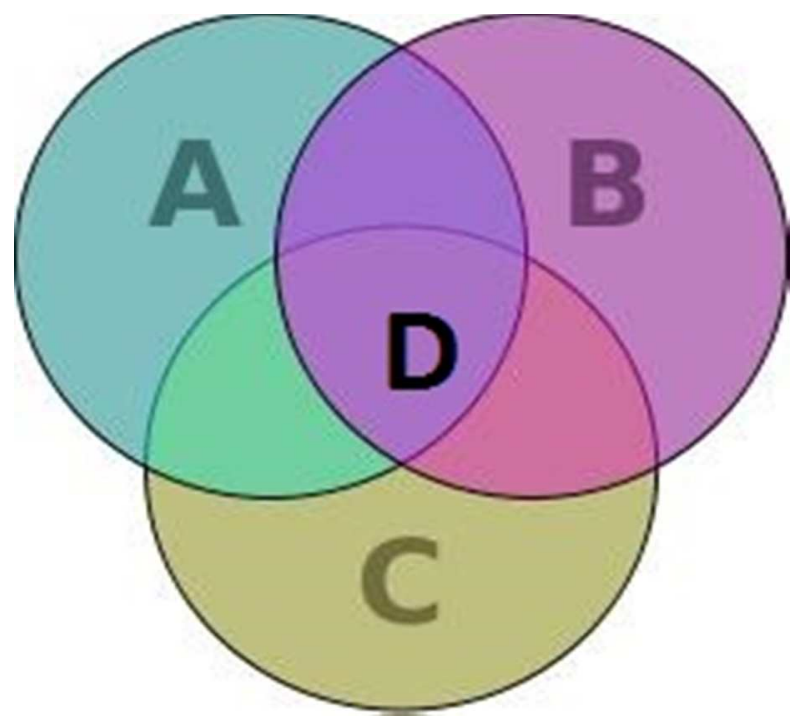

Figure 13. Venn diagram of the interrelationship of the three Laws 
Where:
A. Law No. 28 of 2014 on Copyright (UUHC);
B. Law No. 11 of 2010 on Tangible Cultural Property (UUCB); and
C. Law No. 5 of 2017 on Culture Advancement (UUPK)
D. Intersection of the three laws, especially the area dealing with traditional craft.

The potential problem with the overlapping is shown by traditional craft, such as traditional masks (Topeng Malangan, Topeng Bali, Topeng Madura, etc.). If this craft belongs to UUCB, the legal consequences are: (1) the ownership will be transferred to the State if there are no heirs; (2) anyone can own it by its social function as long as they do not contradict prevailing laws; (3) the expenditure for preservation becomes the burden of the Indonesian Government.

The issuance of UUPK in 2017 creates one important question: is it relevant to differentiate TCE (which are mostly in the form of intangible cultural heritage and is covered in copyright law) and TCE in cultural property (which are mostly tangible cultural heritage). Two reasons can be posed: first, the differentiation between intangible cultural heritage and tangible cultural heritage has no significance from legal point of view, because both TCE and cultural properties are heritage. This notion is supported by the international instrument: WIPOUNESCO Model Provisions ${ }^{53}$, stating: "productions consisting of characteristic elements of the traditional artistic heritage developed and maintained by a community of a country or by individuals reflecting the traditional artistic expectations of such a community, in particular: (i) Verbal expressions, such as folk tales, folk poetry and riddles; (ii) Musical expressions, such as folk songs and instrumental music; (iii) Expressions by action, such as folk dances, plays and artistic forms or rituals; whether or not reduced to a material form; and (iv) Tangible expressions." Cultural properties (cagar budaya) is also "heritage", and UUCB confirms that it "is tangible cultural heritage". So, if both are national heritage, why should formulate them in different regulations which in turn have different legal consequences?

\section{Towards a Sui Generis Model for Cultural Heritage Law}

The question of a sui generis protection system was tackled by the WIPO 2002 document discussing the elements of a sui generis system for the protection of traditional knowledge. The document notes that several countries had requested for an examination of sui generis models for the protection of traditional knowledge. These countries regarded the development of such models as both important and necessary, due to the inadequacy of conventional Intellectual Property Rights to cover the diversity of traditional knowledge. The document acknowledges the difficulties of creating an effective international system without reference to operational national systems, while at the same time it concedes that a sui generis system might hinder the development of a traditional knowledge protection with an international flavor ${ }^{54}$. The document therefore only recommends that several elements might be taken into account in the developments of a sui generis system.

A sui generis intellectual property system is, according to WIP055: "a modification of some of IP system features so as to properly accommodate the special characteristics of its subject matter, and the specific policy needs which led to the establishment of a distinct system". The system might be able to cover the separate elements of traditional knowledge previously uncovered by

\footnotetext{
53 UNESCO and WIPO.

54 WIPO, Intergovernmental Committee on Intellectual Property and Genetic Resources, Traditional Knowledge and Folklore, [website], 2002, p. 3, available from t http://www.wipo.int/meetings/en/details.jsp?meeting_id=4720 (accessed 7 May 2017).

55 Ibid, pp. 13-14.
} 
conventional IP system, including the parts that are unique to a certain country. WIPO therefore recommends several questions to identify the elements of a sui generis system. Several model provisions for the sui generis protection for traditional knowledge have been provided, such as the Model Provisions 1982, the Tunis Model Law 1976, the Panama Law 2000, the South Pacific Model Law 2002, the Bangui Agreement of OAPI (amended in 1999), and the U.S.A. Indian Arts and Craft Act of 1990. All of which have to some extent reflect the elements of protection identified by the questions.

In the case of Indonesia, the characteristics of Indonesian TCE render it problematic for a copyright system coverage. The protection of Indonesian TCE might be better provided by a sui generis IPR-system. Subsequently, development of an Indonesian sui generis system will also have to take into account the following questions.

\section{What is the policy objective?}

WIPO document explains that the way a sui generis system is shaped and defined will depend on a large extent on the policy objectives it is intended to serve. The characteristics of Indonesian TCE might require a protection against misappropriation, a means to encourage creativity, development and innovation of the TCE, and a guarantee of safe and fair (economic) cooperation with other parties.

\section{What is the subject matter?}

The Indonesian traditional knowledge that should be protected will include both tangible and intangible forms of Indonesia's cultural heritage, such as science and technology, various artistic expressions, biodiversity, buildings and monuments, and perhaps prominent individuals in the development of science and/or art.

\section{What criteria should be met?}

The criteria for protection may refer to the existing guidelines for the registration and formation of intangible cultural heritage in Indonesia and Law No. 11 of 2010 on Cultural Property. The TCE qualified for protection might be the 'traditional' expressions of a given community which represent the community's cultural identity and have been transferred from generation to generation; and all man-made or natural structures or geographical spaces in a given region. An element based on the Law No. 20 of Panama might also be added, in which the criteria includes a susceptibility to commercial exploitation.

\section{Who owns the rights?}

In the Copyright Law, the government or the State is the holder of the rights to TCE. The sui generis system should grant the holding of the rights to the communities themselves, taking into account the communities' customary laws, as well as the communal and often anonymous characteristics of TCE, in order to give the communities more control of and responsibilities on their own cultural identity.

\section{What are the rights?}

The rights to be acquired must be relevant to the legitimate interests of the TCE holders, in this case the communities from which the TCE have sprung. These might include the right to exploit economically, to develop, to promote, to sustain, to produce innovations from the TCE, and to protect said TCE from illicit exploitations by unauthorized parties. Nevertheless, the rights granted must not limit the rights of the whole Indonesian society, and the world society, to appreciate and use the TCE, provided that there are no violations/misappropriations involved. Exceptions might be given to educational and other non-profitable purposes. 


\section{How are the rights acquired?}

The rights might be acquired through registration and recording in a national database. The application for registration must be in the name of the relevant community and recognized by the community itself.

\section{How to administer and enforce the rights?}

The administration and enforcement of the rights might be conducted through a law on the protection of National Cultural Heritage which covers both tangible and intangible cultural properties. Punishment for offences might be based on existing laws and the model laws provided by WIPO.

\section{How are the rights lost or how do they expire?}

Both Tunis Model Law of 1976 and Model Provisions of 1982 declare that the rights held by indigenous communities are unlimited in time. Nevertheless, Indonesian sui generis system might include the provision that the rights might expire if the relevant community no longer exists.

The above points are only the basic principles of cultural heritage protection. Further details might be expounded in a law and its implementation regulations.

\section{CONCLUSION}

Indonesian Copyright Law is inadequate to accommodate the whole protection for TCE. Meanwhile, Indonesian laws that regulate traditional knowledge are overlapping and incapable to comprehensively cover national cultural heritage. A new regulation is subsequently needed to implement the protection. WIPO recommends that each country design its own law on traditional knowledge protection (sui generis), and this path seems to be the best route for Indonesia to truly protect its cultural heritage. In order to design such a sui generis law, Indonesian lawmakers may follow the guidelines provided by WIPO in the form of predesigned questions, as well as a number of model laws such as Tunis Model Law and Panama Law. The sui generis law should grant the rights for protection to indigenous communities, as well as accommodating their interests and views.

\section{References}

Adewopo, A., "Protection of and Administration of Folklore in Nigeria", SCRIPTed, vol. 3, no. 1, 2006, pp. 1-10.

Antons, C., "Asian Borderlands and the Legal Protection of Traditional Knowledge and Traditional Cultural Expressions”, Modern Asian Studies, vol. 47, no. 4, 2013, pp. 1403-1433.

Aragon, L. V., "Copyrighting Culture for the Nation? Intangible Property Nationalism and the Regional Arts of Indonesia”, International Journal of Cultural Property, vol. 19, no. 3, 2012, pp. 269-312.

Burri, M., “Digital Technologies and Traditional Cultural Expressions: A Positive Look at a Difficult Relationship”, International Journal of Cultural Property, vol. 17, no. 1, 2010, pp. 33-63.

Busch, A. F., Protection of Traditional Cultural Expressions in Latin America, Berlin, Springer, 2015.

Collins, S., "The Commoditisation of Culture: Folklore, Playwriting and Copyright in Ghana”, PhD Thesis, University of Glasgow, 2015.

Endraswara, S., Folklor Nusantara [Indonesian Folklore], Yogyakarta, Ombak, 2013.

Graber, C. B. and M. Burri, Intellectual Property and Traditional Cultural Expressions in a Digital Environment, Cheltenham, Edward Elgar, 2008.

Hinz, M. O., "The Swakopmund Protocol on the Protection of Traditional Knowledge and Expressions of Folklore", Namibia Law Journal, vol. 3, no. 1, 2011, pp. 101-112.

Kuruk, P., “African Customary Law and the Protection of Folklore”, Copyright Bulletin, vol. 26, no. 2, 2002, pp. 4-32. 
Kusumadara, A., "Pemeliharaan dan Pelestarian Pengetahuan Tradisional dan Ekspresi Budaya Tradisional Indonesia: Perlindungan Hak Kekayaan Intelektual dan Non-Hak Kekayaan Intelektual [Protection and Preservation of Indonesian Traditional Knowledge and Cultural Expressions: Protection of Intellectual Property Rights and Non-Rights]", Ius Quia Iustum, vol. 18, no. 1, 2011, pp. 20-41.

Kusumadara, A., "Protection and Sustainability of Indonesian Traditional Knowledge and Folklore: Legal and NonLegal Measures", US-China Law Review, vol. 8, no. 6, 2011, pp. 548-565.

Kutty, P. V., National Experiences with the Protection of Expressions of Folklore/Traditional Cultural Expressions: India, Indonesia and the Philippines, Geneva, WIPO Publications, 2002.

Mahadewi, K. J., "Budaya Hukum Dalam Keberlakuan Undang-Undang Nomor 28 Tahun 2014 Tentang Hak Cipta Pada Pengrajin Perak Di Bali [Legal Culture in the Application of Indonesian Law No. 8 of 2014 on Copyright to Balinese Silversmiths]", Udayana Master Law Journal, vol. 4, no. 2, 2015, pp. 205-218.

Nahor, R. J., "Perlindungan Hukum Hak Cipta Folklor Atas Tari-Tarian Rakyat Indonesia [Copyright Law Protection of Indonesian Folklore Dances]”, Master Thesis, Atma Jaya University, 2013.

No name, "Seni Budaya, Tak Ada Perlindungan Secara Internasional [No international protection for art and culture]", Kompas, 1 September 2009.

No Name, "Menembus Brunei, Gamang di Negeri Sendiri [Breakthrough in Brunei, uneasiness in home country]", Kompas, 22 October 2010.

Núñez, R. G., (2008). "Intellectual Property and the Protection of Traditional Knowledge, Genetic Resources and Folklore: The Peruvian Experience”, in A. von Bogdandy and R. Wolfrum, (eds.), Max Planck Yearbook of United Nations Law Online, vol. 12, no. 1, 2008, pp. 487-549.

Nurmansyah, M. A., S. Sukmawan and Hamamah, Strategi Pelestarian Seni Tradisi: Studi Kasus Kelompok Kesenian Tradisional Lengger di Kabupaten Jember: Laporan Hasil Penelitian: Hibah Penelitian Strategis Nasional DIPA Universitas Brawijaya Tahun Anggaran 2010 [Traditional Art Preservation Strategy: Case Study of Traditional Art Community "Lengger" in Jember Residency], Research Report, Malang, Brawijaya University, 2010.

Pang, L., Cultural Control and Globalization in Asia: Copyright, Piracy, and Cinema. London, Routledge, 2006.

Phillips, J., “Australia's Heritage Protection Act: An Alternative to Copyright in the Struggle to Protect Communal Interests in Authored Works of Folklore", Pacific Rim Law \& Policy Journal Association, vol. 18, no. 3, 2009, pp. 547573.

Pilch, J. T., Traditional Cultural Expression, [Library Copyright Alliance], 2009,

http://www.librarycopyrightalliance.org/storage/documents/issuebrieftce.pdf (accessed 7 May 2017).

Purwaningsih, E., (2012). "Partisipasi Masyarakat dalam Perlindungan Hukum terhadp Kekayaan Intelektual Warisan Bangsa [Public Participation in Legal Protection of Cultural Heritage]", Jurnal Masalah-Masalah Hukum FH-UNDIP, vol. 4, no. 1, 2012, pp. 42-49.

Reyssent, M., "Patung Arjuna dihancurkan, mengapa patung polisi dibiarkan" [Why the statue of Arjuna is destroyed but police statues are allowed], Kompasiana, 16 February 2016,

https://www.kompasiana.com/mikereys/patung-arjuna-dihancurkan-mengapa-patung-polisidibiarkan_56bfd884ad7e61fa0f44608b (accessed 10 May 2017).

Shankar, G., "From Subject to Producer: Reframing the Indigenous Heritage through Cultural Documentation Training", International Journal of Intangible Heritage, vol. 5, 2010, pp. 14-24.

Sinaga, V. S., (2014). “Faktor-Faktor Penyebab Rendahnya Penggunaan Hak Kekayaan Intelektual di Kalangan Usaha Kecil Menengah Batik [The Factors behind the Low Use of Intellectual Property Rights among Small and Medium Batik Enterprises]", Ius Quia Iustum, vol. 21, no. 1, 2014, pp. 61-80.

Srinivas, K. R., "Protecting Traditional Knowledge Holders' Interests and Preventing Misappropriation Traditional Knowledge Commons and Biocultural Protocols: Necessary but Not Sufficient?”, International Journal of Cultural Property, vol. 19, no. 3, 2012, pp. 401-422.

Stelmach, J. and B. Brozek, Methods of Legal Reasoning. Dordrecht, Springer Netherlands, 2006.

Susanti, D. I., (2004). "Perlindungan Hukum Hak atas Kekayaan Intelektual bagi Kerajinan Topeng Malang dalam Kerangka Otonomi Daerah [Intellectual Property Rights Protection for Malang Masks Craft in the Framework of Regional Autonomy]". Justitia et Pax, vol. 25, no. 2, 2004, pp. 191-201.

Susanti, D. I., "Integrating the Experiences in Local Knowledge into the Higher Education Using Digital Tools", Seminar Paper, Malang, Widya Karya Catholic University, 2014. 
Susanti, D. I., "Penafsiran Hukum yang Komprehensif terhadap Hak Moral dan Hak Ekonomi dalam UndangUndang Hak Cipta [A Comprehensive Legal Interpretation of the Moral and Economic Rights in Copyright Law]", Research Report, Malang, Widya Karya Catholic University, 2014.

Susanti, D. I., Penafsiran Hukum yang Komprehensif Berdasarkan Lingkar Hermeneutika [A Comprehensive Legal Interpretation Based on Hermeneutic Circle]. Malang, Indonesian Philosophical Studies, 2015.

Susanti, D. I., Hak Moral dan Hak Ekonomi dalam Hak Cipta: Konsep, Sejarah, dan Perbandingan [Moral and Economic Rights in Copyrights: Concept, History and Comparison]. Malang, Widya Sasana Publication, 2016.

Susanti, D. I., “Ekspresi Budaya Tradisional dalam Undang-Undang Hak Cipta Indonesia: Kajian Maksud Pembuat Undang-Undang dan Kajian Perbandingan Hukum [Traditional Cultural Expressions in Indonesian Copyright Law: Study on the Intent of Lawmakers and on Legal Comparisons], Research Report, Malang, Widya Karya Catholic University, 2016.

Susanti, D. I. et al., "The Problem of Copyright for Traditional Cultural Expressions in Indonesia: The Example of the 'Malang Masks'”, Journal of Law, Policy and Globalization, vol. 29, 2014, pp. 57-71.

Susanti, D. I. et al., "Partialities in the Methods of Legal Interpretation" Journal of Law, Policy and Globalization, vol. 32, 2014, pp. 57-64.

Torremans, P., Intellectual Property Law. Oxford, Oxford University Press, 2006.

Torsen, M., "Intellectual Property and Traditional Cultural Expressions: A Synopsis of Current Issues" Intercultural Human Rights Law Review, vol. 3, 2008, pp. 199-214.

UNESCO, Berinvestasi dalam Keanekaragaman Budaya dan Dialog Antarbudaya [Investing in Cultural Diversity and Intercultural Dialogues], trans. Dwi Indrasari, Paris, UNESCO, 2011.

UNESCO and WIPO, Model Provisions for National Laws on the Protection of Expressions of Folklore against Illicit Exploitation and Other Prejudicial Actions [WIPO], 1985, http://www.wipo.int/wipolex/en/details.jsp?id=6714 (accessed 18 June 2017).

Wilkinson, M. A. and N. Gerolami, "The Author as Agent of Information Policy: The Relationship between Economic and Moral Rights in Copyright", Government Information Quarterly, vol. 26, no. 2, 2009, pp. 321-332.

WIPO, Intergovernmental Committee on Intellectual Property and Genetic Resources, Traditional Knowledge and Folklore, [WIPO], 2002, http://www.wipo.int/meetings/en/details.jsp?meeting_id=4720 (accessed 7 May 2017).

WIPO, Glossary of Key Terms Related to Intellectual Property and Traditional Knowledge. [WIP0], 2012, http://www.wipo.int/meetings/en/doc details.jsp?doc id=167787 (accessed 7 May 2017).

Yang, C. C., "A Comparative Study of the Models Employed to Protect Indigenous Traditional Cultural Expressions", Asian-Pacific Law \& Policy Journal, vol. 11, no. 2, 2011, pp. 50-84.

Zhang, L., Protecting Traditional Cultural Expressions from a Copyright Perspective, [IPO], 2008, http://www.ipo.org/wp-content/uploads/2013/03/LizaZhang.pdf (accessed 20 July 2017). 